\title{
Activity Patterns of Sand Fly (Diptera: Psychodidae) Species and Comparative Performance of Different Traps in an Endemic Cutaneous Leishmaniasis Focus in Cukurova Plain, Southern Anatolia, Turkey
}

\author{
Ozge E. Kasap ${ }^{1}$, Asli Belen ${ }^{1}$, Sinan Kaynas ${ }^{1}$, Fatih M. Simsek ${ }^{3}$, Levent Biler ${ }^{1}$, Nihal Ata ${ }^{2}$, \\ Bulent Alten ${ }^{1}$ \\ ${ }^{1}$ Hacattepe University, Faculty of Science, Department of Biology, Ecological Sciences Research Laboratory, \\ Beytepe, Ankara, Turkey \\ ${ }^{2}$ Hacattepe University, Faculty of Science, Department of Statistics, Ankara, Turkey \\ ${ }^{3}$ Adnan Menderes University, Art and Science Faculty, Biology Department, Ecology Section, Aydin, Turkey
}

Received August 18, 2008

Accepted December 15, 2008

\begin{abstract}
An entomological survey for sand flies was conducted from May to October 2006 in a village near an endemic focus of cutaneous leishmaniasis in Cukurova Plain, south Anatolia, Turkey. Standard $\mathrm{CDC}$ light traps, $\mathrm{CO}_{2}$ traps, sticky traps, mouth aspirators, animal-baited traps and human landing collection were used to determine species composition, density and nocturnal activity of sand fly species. BG-Sentinel Trap, a novel monitoring trap originally developed to attract mosquitoes, was also tested to investigate its efficiency for sand flies. Overall, 4048 specimens belonging to four species of genus Phlebotomus Rondani et Berté 1840 and two of genus Sergentomyia França et Parrot 1920 were collected. Phlebotomus tobbi Adler, Theodor et Lourie 1930, the proven vector of Leishmania infantum Nicolle 1908 was found to be the most abundant (65.6\%) species while P. sergenti Parrot 1917, the proven vector of L. tropica (Wright, 1903) in Turkey accounted for $0.1 \%$ of the sand flies that were identified. Other species, P. perfiliewi galilaeus (Theodor 1958), P. papatasi (Scopoli, 1786), Sergentomyia dentata (Sinton, 1933) and Sergentomyia theodori (Parrot, 1942) represented 31\%, 2\%, 1.5\% and $0.3 \%$ of the sand fly fauna, respectively. Aggregate population of sand flies was found to be the lowest in May. Population size rose through June and July, with the highest peak in August, and decreased through September and October. Among the traps used, $\mathrm{CO}_{2}$ traps were found to offer a more suitable and productive method than others for both estimating the species composition and the population density of sand flies in the study area. Studies on the nocturnal activity indicated that even the number of captures declined rapidly during dusk period, between 04.00 and 06.00 $\mathrm{h}$, in general, no significant hourly pattern was determined neither the species prevalence nor the nocturnal activity of the species. According to statistical analysis the variation in hourly nighttime temperature did not influence the nocturnal activity of the species whereas the number of collected sand flies during nocturnal period was strongly associated with relative humidity.
\end{abstract}

Leishmania, Phlebotomus, Sergentomyia, blood sucking insects, nocturnal activity

The prevalence of anthroponotic cutaneous leishmaniasis (CL) which is caused mostly by Leishmania tropica (Wright, 1903) was high before 1950's in the southeastern Anatolia region of Turkey. After the activation of the Malaria Control Programmes all over the country, the incidence of CL has decreased. The reduced number of infected reservoirs, low density of vector populations and improvement of socio-economic life of the communities resulted in limiting the distribution of CL cases within the southeastern Anatolia region. Although leishmaniasis has been sporadically observed in other parts of the country, over the past 10 years there has been a significant increase in the incidence of CL cases in Cukurova Basin, and this region has become the second endemic focus of CL in Turkey. More than 4500 CL cases have been recorded during the past eight years by the Cukurova University Tropical Diseases Research Centre and Department of Dermatology, School of Medicine (An ony mous 2007).

Previous studies aiming at determining the species composition and distribution patterns of sand flies in Cukurova Basin revealed nine Phlebotomus Rondani et Berté 1840 and two

Address for correspondence:

Ö. Erışöz Kasap

Hacattepe University

Faculty of Science, Department of Biology

Ecological Sciences Research Laboratories

06800 Beytepe, Ankara, Turkey

Phone: +90 3122976435

Fax: +90 3122992028

E-mail: ozgeerisoz@yahoo.com

http://www.vfu.cz/acta-vet/actavet.htm 
Sergentomyia França et Parrot 1920 species. In this region, Phlebotomus tobbi Adler, Theodor et Lourie 1930 was found to be the most abundant $(71.3 \%)$ species while P. sergenti Parrot 1917 , the proven vector of L. tropica in Turkey represented only 3\% of the sand fly fauna (Simsek et al. 2007). According to the results of recent investigations on the identification of vector species in this region, Leishmania infantum Nicolle 1908 was isolated in a CL focus from both $P$. tobbi specimens and local human patients for the first time (Svobodová et al. 2009). All these data show that extensive studies on the population density, seasonal population dynamics and circadian activity of sand fly species including $P$. tobbi are needed to improve our knowledge of leishmaniasis transmission dynamics in this area.

This paper gives the results of an investigation to determine the species composition, seasonal fluctuations of given populations and nocturnal activity patterns of different sand fly species in a village located at the centre of an endemic focus of CL in Cukurova Plain, Southern Anatolia, Turkey. Effects of variations in hourly nighttime temperature and relative humidity on the nocturnal activity patterns of the species were also studied. Besides, in comparison to other trap types, BG-Sentinel Trap, a novel-monitoring trap originally developed to attract mosquitoes, was also tested to determine its efficiency for the monitoring of sand fly species.

\section{Materials and Methods}

Study area

Field studies were conducted in the Camili village $\left(37^{\circ} 20^{\prime} 05^{\prime \prime} \mathrm{N}, 35^{\circ} 36^{\prime} 42^{\prime \prime} \mathrm{E}\right)$ in Cukurova Plain, South Anatolia, from May to October 2006. This village is located at the centre of an endemic focus of CL and has a high sand fly density throughout the season (Simsek et al. 2007). Camili is bound by West Taurus Mountains to the West; the mountain ranges of Taurus and Anti-Taurus to the North, and the Amanos Mountains to the East. The village is about $55 \mathrm{~km}$ northeast of the Adana city at the altitude of $205 \mathrm{~m}$ above sea level (a.s.1.). Most of the area is fertile ("mollisol" soil) and used for agricultural activities, however, young Pinus and Abies forests are also cultivated. Citrus orchards and cotton fields are common around the village. The climate in the study area is classified as temperate, with a short wet season. The mean annual precipitation is $636.8 \mathrm{~mm}$ and with $66 \%$ relative humidity, and the mean annual temperature is $18.7^{\circ} \mathrm{C}$. The maximum and minimum average monthly temperatures are $34.4{ }^{\circ} \mathrm{C}$ and $5.0{ }^{\circ} \mathrm{C}$, respectively. The population of the village is approximately 220 inhabitants. Residents live in single-family houses built from briquette, adobe, stone and cement, surrounded by gardens with henhouses and sheep or cowsheds. Although the animal shelters are closed with four walls and a roof, most villagers prefer to keep their animals in simple open sheds consisting of a roof made of bamboo supported by pillars during the summer season.

Collection methods

Sand flies were collected monthly from May to October 2006 using a Centre for Disease Control (CDC) light trap (John W. Hock, USA) and a $\mathrm{CO}_{2}$ light trap $(0.5 \mathrm{~kg}$ dry ice) placed in yards and set up about $1.5 \mathrm{~m}$ above ground. Four sticky paper traps $(20 \times 30 \mathrm{~cm}$ papers coated with castor oil) were rolled up and placed in the holes of the wall that surrounds the chicken coop. The BGS-Trap has been recently developed by BioGents $\mathrm{GmbH}$ (Regensburg, Germany) and utilizes patent-pending technology from the University of Regensburg. Two BG-Sentinel traps containing two different attractants (the BG-Lure $\mathbb{R}$ and Octenol lure) were also placed on the ground. Each trap used in the study was placed outside the same house and animal shelter between 18.00 and $06.00 \mathrm{~h}$. The traps were set up at least $15 \mathrm{~m}$ from each other and were changed every two hours. As the traps were changed, new ones were placed in the same location. Human landing collection and collections using a cattle baited trap $(3 \times 3 \times 2 \mathrm{~m})$ were also performed over the same $12 \mathrm{~h}$ period. All sand flies landing on the exposed legs of human collectors and entering into cattle baited trap were captured during $10 \mathrm{~min}$ in every two hours. Indoor collections were performed using mouth aspirators.

Sand fly identification

Specimens collected from each trap were stored in $96 \%$ alcohol for morphological identification. Identifications were based on the morphology of the male genitalia and female spermatechae and pharynges using the keys of Theodor (1958), Artemiev (1980), Lewis (1982) and Killick-Kendrick et al. (1991).

Recording climatic conditions

To determine whether the local variations in hourly temperature and relative humidity (RH) might affect abundance or activity of sand flies in the study area, we placed two data loggers (iButton Hygrochron, DS 1923) associated with each trap. One of them was programmed to record temperature and humidity every $6 \mathrm{~h}$ and left at the study area during the whole year. Every month, we retrieved temperature and humidity data from the data logger and obtained daily and monthly temperature and humidity averages. The other one was programmed to record temperature and humidity every half hour and used only during one night in September when the traps were set to investigate if there is any relationship between the nightly variations in climatic conditions and the nocturnal activity of sand flies. 
Statistical Analyses

In order to ensure normality and homogeneity of variances before subjecting to statistical analysis, data on the number of flies collected were square-root transformed. The significance of the effect of species, trap and sex on the number of animals that come to the trap was analyzed using a mixed model analysis of variance (ANOVA), in which species and sex constituted the random factors, while trap constituted the fixed factor. When significant effects of traps were established $(p<0.05)$, differences among traps were tested using Student-Newman-Keuls multiple comparison test. A stepwise multiple regression was conducted to assess the effects of average night-time temperature, average night-time humidity and collection period on the number of flies caught during one study night in September. Basic correlation matrices used to investigate the existence of a correlation between the abundance of the sand flies, average monthly temperature and average monthly relative humidity in the study area.

\section{Results}

A total of 4048 sand flies belonging to four species of the genus Phlebotomus and two of the genus Sergentomyia were collected. Females comprised $20 \%$ of catches during the study period. Of the collected total, Phlebotomus tobbi was found to be the most abundant $(65.6 \%)$ species while $P$. sergenti, the proven vector of $L$. tropica in Turkey accounted for $0.1 \%$ of the sand flies that were identified. Other species, P. perfiliewi galilaeus (Theodor 1958), P. papatasi (Scopoli, 1786), Sergentomyia dentata (Sinton, 1933) and S. theodori (Parrot, 1942) represented 31\%, 2\%, 1.5\% and $0.3 \%$ of the sand fly fauna, respectively (Table 1). During the study period, aggregate population of sand flies was found to be the lowest in May. Population size rose during June and July, with the highest peak in August, and decreased during September and October.

Table 1. Relative abundance of $P$. tobbi, P. perfiliewi galilaeus, P. sergenti and Sergentomyia spp. by month in Camili from May to October

\begin{tabular}{|l|c|c|c|c|c|}
\hline Month Species & $\begin{array}{c}\text { P. tobbi } \\
(\%)\end{array}$ & $\begin{array}{c}\text { P. papatasi } \\
(\%)\end{array}$ & $\begin{array}{c}\text { P. sergenti } \\
(\%)\end{array}$ & $\begin{array}{c}\text { P. perf. gal. } \\
(\%)\end{array}$ & $\begin{array}{c}\text { Sergentomyia spp. } \\
(\%)\end{array}$ \\
\hline May & 68.75 & 18.75 & 0 & 0 & 12.5 \\
\hline June & 43.95 & 8.07 & 0 & 44.39 & 3.58 \\
\hline July & 71.09 & 2.89 & 1.15 & 15.6 & 9.24 \\
\hline August & 59.49 & 0.63 & 0 & 38.76 & 1.11 \\
\hline September & 83.04 & 3.3 & 0.2 & 12.71 & 0.72 \\
\hline October & 80.82 & 1.37 & 0 & 17.8 & 0 \\
\hline
\end{tabular}

The recorded average monthly temperature and $\mathrm{RH}$ values ranged between $23.7-31.2{ }^{\circ} \mathrm{C}$ and 46.6-66.8\%, respectively. In August, when the maximum number of sand flies (2 523) was collected, the average temperature and $\mathrm{RH}$ were found to be $30.5^{\circ} \mathrm{C}$ and $56.8 \%$, respectively; while the minimum number of sand flies was sampled in May (16) with an average temperature of $23.7^{\circ} \mathrm{C}$ and $66.8 \%$ relative humidity (Fig. 1). There were no significant correlations between the abundance of sand flies, average monthly temperature $(\mathrm{r}=0.5, p=0.3)$ and average monthly relative humidity $(\mathrm{r}=-0.19, p=0.7)$.

The relative abundance of each species by month is shown in Table 1. Phlebotomus tobbi was the predominant species identified in May, July, August, September and October, accounting for $>50 \%$ of the collection each month, whereas in June it accounted for $44 \%$ of the total collection. Although no specimen of $P$. perfiliewi galilaeus was identified in May, it became the predominant species in June $(\sim 45 \%)$. Later in the season, although it became less abundant, it was the second predominant species during the study period. Phlebotomus papatasi and Sergentomyia spp. were found to be rare throughout the study period. Neither P. papatasi nor Sergentomyia spp. accounted for more than $20 \%$ of the sand flies collected each month. Phlebotomus sergenti was collected only in July and September and accounted for $\sim 1.2$ and $0.2 \%$ of the total collection respectively.

The number of sand flies collected using different types of traps during the study period is presented in Table 2 . Almost all sand fly species were commonly captured by $\mathrm{CO}_{2}$ light traps and standard CDC light traps. Approximately $71.2 \%$ of the total collection was made 


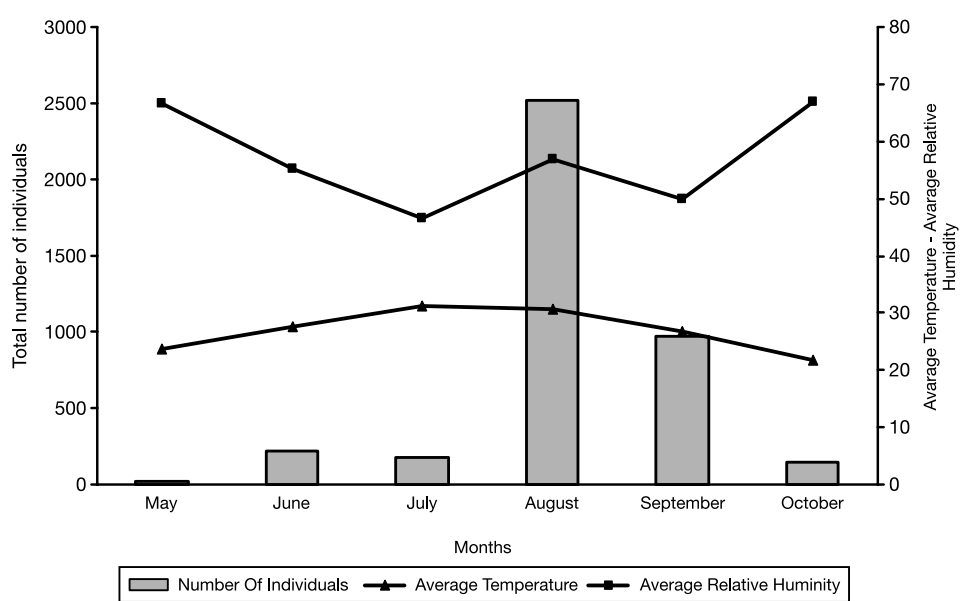

Fig. 1. Total number of sand flies collected each month and variation of average monthly temperature and relative humidity in the study area from May to October 2006

up using $\mathrm{CO}_{2}$ light traps. Twenty-one percent and 5.2\% of sand flies were collected using CDC light traps and animal baited traps, respectively. Collections using BG-Sentinel trap with octenol Lure and BG-Lure constituted 0.98 and $1.01 \%$ of the total collection. Neither human landing collections $(0.3 \%)$ nor sticky traps $(0.2 \%)$ showed a high efficiency during the study. Results of three-way analysis of variance (ANOVA) revealed a significant interaction between the collection methods and the number of individuals collected $(p=$ 0.032), whereas there was no significant interaction between the trapping methods and the proportion of males and females collected $(p=0.107)$. When significant effects of traps were established $(p<0.05)$, differences among traps were tested using Student-NewmanKeuls multiple comparison test. Student-Newman-Keuls test exposed that sticky papers, animal baited trap, BG-S with octenol, BG-S with BG lure, aspirator, and human landing collection displayed similar capturing performance, whereas $\mathrm{CO}_{2}$ and standard CDC light traps differed from the others $(p<0.05)$ and they were found to be more effective in terms of the total number of individuals collected.

A total of 1042 phlebotomine sand flies were collected throughout one night in September. Males were found to be 4.7-fold more abundant than females. Results with respect to the nocturnal activity indicated that even though the number of captures declined rapidly between 04.00 and $06.00 \mathrm{~h}$, there was no significant hourly pattern either in the species prevalence or in the activity of the species (Fig. 2). Phlebotomus tobbi $(84.3 \%)$ was found to be predominant throughout the night, followed by $P$. perfiliewi galilaeus $(11.7 \%)$, P. papatasi $(3.1 \%)$ and Sergentomyia spp. (0.9\%). Between $04.00-06.00$ h, only P. tobbi and $P$. perfiliewi galilaeus were collected. The nocturnal activity pattern and variation in temperature and relative humidity in the study station is represented in Fig. 3. Multiple regressions testing effects of collection intervals and hourly nighttime temperature on the number of collected sand flies revealed no significant relationships. However, the number of sand flies was strongly and negatively associated with hourly nighttime humidity $\left(\mathrm{R}^{2}=\right.$ 0.729 , df $=11, p=0.034$ ).

\section{Discussion}

This study is the first detailed research in terms of species composition, density and nocturnal activity of sand flies in an endemic focus of cutaneous leishmaniasis in Cukurova 


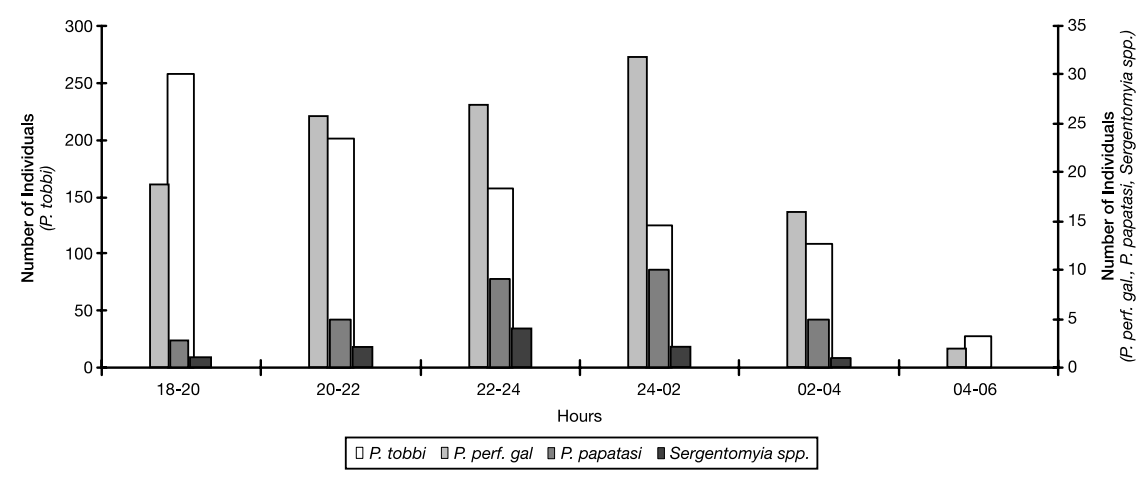

Fig. 2. Hourly activity pattern of the sand fly species in September in Camili

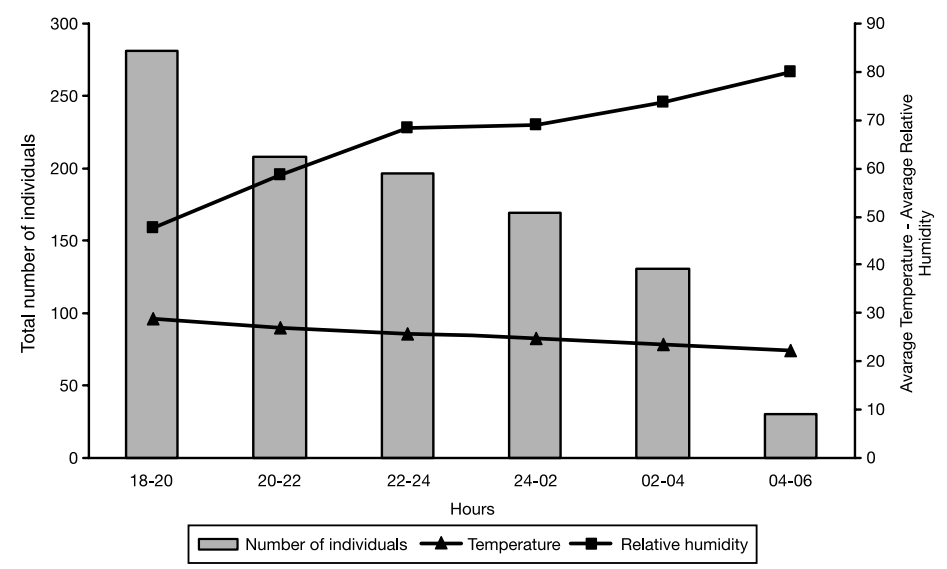

Fig. 3. Nocturnal activity pattern of the sand flies and variation in temperature and relative humidity in September in Camili

Plain, South Anatolia, Turkey. Trapping over the summer season revealed that $P$. tobbi is the most abundant species $(65.6 \%)$ in this region. Our finding of high population density for $P$. tobbi compares favourably with our previously published data for which this species is the predominant sand fly species in the lowlands (0-300 m a.s.l.) of the Cukurova Region (Simsek et al. 2007). However, according to previous results, $P$. perfiliewi was very rare $(0.02 \%)$ in the Adana Province, whereas we found this species as the second most abundant (31\%) species. Both the previous and recent findings showed that P. sergenti, the proven vector of $L$. tropica in Turkey, was represented with small populations in the study area. The village in which we conducted our study is located at an altitude of $180 \mathrm{~m}$ a.s.l. and P. sergenti accounted for only $0.1 \%$ of the total collection. The observed low abundance of P. sergenti may be another indicator that this species is most common at $500-700 \mathrm{~m}$ a. s. 1. (Büttiker and Lewis 1983), and described as a mountainous species (Seyedi Rashti and Nadim 1992).

Although sand fly abundance was not strongly and significantly influenced by the variations in average monthly temperature and relative humidity during the six months of survey, the maximum number of sand flies was recorded in the hottest and driest season between June and September when the average temperature was comparatively high (26.9 to $31.2{ }^{\circ} \mathrm{C}$ ), the relative humidity was low $(46.6$ to $56.8 \%$ ) and the rainy days ranged 


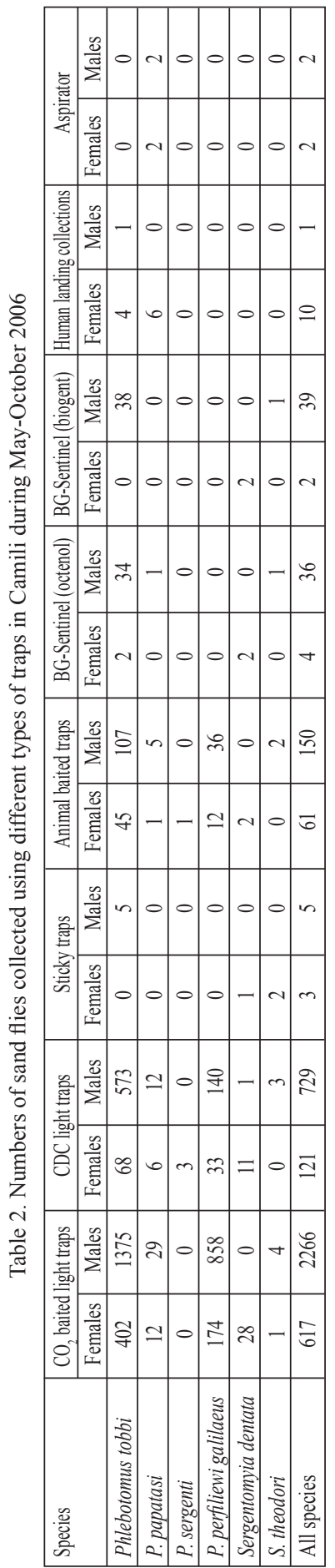

between 1.5 to 3.5 days. Singh (1990) studied the role of climatic factors in the seasonal distribution of sand flies in the arid areas of India and revealed that the majority of species preferred comparatively higher temperatures and low $\mathrm{RH} \%$, a prerequisite for survival in arid and semi-arid conditions. The abundance of Lutzomyia vexator (Coquillett, 1907) in New York was reported not to be influenced by local variation over time in temperature and humidity, but the number of captures of sand flies was strongly and positively associated with the percent slope, suggesting some feature of topography to be a good predictor of sand fly abundance (Ostfeld et al. 2004). Although our findings contribute to our understanding of the factors affecting sand fly abundance and dynamics in the study area, further studies of topographic characteristics of the area, distribution and the dynamics of the reservoir hosts are required to better describe these patterns.

Although $\mathrm{CDC}$ light traps and $\mathrm{CO}_{2}$ traps are used extensively in field studies of sand flies (Alexander 2000), sticky traps have no known attractiveness and have generally been used for determining species composition of an area as they randomly sample the species where they are set. However, while unbiased sticky traps provide more realistic results than $\mathrm{CDC}$ light traps that could attract additional phototropic sand flies, previous studies revealed that the effective range of CDC light traps were less than 5 $\mathrm{m}$ (Wheeler et al. 1996). Therefore, although the results obtained from both $\mathrm{CDC}$ light traps and $\mathrm{CO}_{2}$ traps may not be reliable with respect to human-vector contact, in terms of the efficiency of the capturing method, these two trapping methods appeared to be the most productive for both estimating the number of sand flies and the species composition in the study area, in agreement with previous studies. Veronesi et al. (2007) reported that when compared to sticky traps, $\mathrm{CO}_{2}$ traps were found to be more effective in collecting sand flies in northern Italy and addition of a light source improved the catches. The BG-Sentinel trap was originally developed to capture adult Aedes aegypti (Linnaeus 1762) as a monitoring tool and as an attempt to reduce adult mosquito density. The BG-Lure ${ }^{\circledR}$ is an effective mosquito attractant used in the BG-Sentinel \#2880 and other BioQuip mosquito traps. It is packaged in a mesh dispenser that releases a combination of non-toxic substances found on human skin (lactic acid, ammonia, and fatty acids). Octenol lure, the other attractant used in this study, is reported to have pheromone-like properties. It is used by vector control professionals and researchers to enhance the effectiveness of mosquito traps. Even though this novel trap proved to be a reliable and standardized tool for collecting A. aegypti in urban areas (Maciel-deFreitas et al. 2006) and its attractiveness was also recorded 
for a range of other anthropophagic mosquitoes, the low efficiency of this method in our study showed that BG-Sentinel trap may not be a useful alternative for monitoring sand flies. Beavers et al. (2004) evaluated the efficiency of 1-octen-3-ol and $\mathrm{CO}_{2}$ for catching sand flies in southern Egypt and showed that P. papatasi, the most abundant species in the study area was more attracted to $\mathrm{CO}_{2}$ baited traps than to those baited with octenol. They also did not find any synergistic interaction between $\mathrm{CO}_{2}$ and octenol in terms of attracting sand flies. Similar results were recorded by Bernier et al. (2008). According to the results of trapping experiments in Bahrin, Egypt using $\mathrm{CO}_{2}$ (alone), $\mathrm{CO}_{2}+$ octenol and $\mathrm{CO}_{2}+$ human hair baited traps, addition of chemical lures or odors did not enhance the trap collections.

The nocturnal activity patterns of sand flies have been recorded for Old World species in many studies (Roberts 1994; Guernaoui et al. 2006; Coleman et al. 2007). According to our results obtained in the late summer season, sand fly activity was not significantly different over time even though total counts decreased between $04.00-06.00 \mathrm{~h}$. No significant difference was found in the species prevalence throughout the nights. Phlebotomus tobbi seemed to be active and predominant until sunrise. The most important factor affecting sand fly nocturnal activity in this study was found to be the relative humidity. Activity started just before the sunset and increased rapidly when the average $\mathrm{RH}$ was $47.7 \%$. As the humidity increased to 58.6 and $69.1 \%$, activity remained almost constant until midnight and decreased rapidly when the recorded average humidity values were over $70 \%$. Our results agree with those of Roberts (1994) who found that there was no significant hourly activity pattern for the sand flies in Oman and the most important factor affecting sand fly activity was low humidity, followed by low wind velocity and high temperature. It is clear that activity of sand flies is continuous through the night and relative humidity has a significant effect on the nocturnal activity in our study area. However, many investigations demonstrated the existence of seasonal variations in the nocturnal activity of sand flies. Coleman et al. (2007) showed that in Southern Iraq, the peak activity period shifted from early evening (20.00-22.00 h) in April and October to late night (22.00-24.00 h) in May and June. Similarly, in Morocco the sand fly activity was found to be continuous all night in August, whereas in October the activity declined rapidly after midnight (Guerna oui et al. 2006). Therefore, more detailed studies with respect to the seasonal variations and the effects of abiotic conditions, other than temperature and relative humidity, such as cloud cover, wind velocity and lunar cycle on the nocturnal activity of sand flies may improve our knowledge of the behaviour in this epidemiologically important area.

The overall percentage of male sand flies $(80 \%)$ recorded during the study period is consistent with other published data. Morrison et al. (1995) reported that during the 10 months of their survey in an endemic region of visceral leishmaniasis in Colombia, male Lutzomyia longipalpis (Lutz and Neiva, 1912) composed $60 \%$ and $83 \%$ of the collections conducted at the pigpen and at the cattle corral, respectively. Similar results were obtained by Reza and Mansour (2006) who collected significantly more males than females of both $P$. papatasi $(85 \%)$ and $P$. sergenti $(70 \%)$. According to the results of a more recent study conducted in the Indian state of Bihar, males and non-fed females of Phlebotomus argentipes (Annandale and Brunetti, 1908) comprised $>60 \%$ of the total collections (Dinesh et al. 2008). Previous studies on sand fly abundance revealed that the sex ratio of L. longipalpis was more male biased at higher sand fly densities (Quinnell and Dye 1994) and when there were more available hosts (Dye et al. 1991). It is known that male sand flies arrive on their host first, form an aggregation and wait for the females for mating. This "lekking" behaviour of the males is believed to allow them to disperse high levels of sex pheromone to attract females and increase their chances to mate (Morrison et al. 1995; Killick-Kendrick 1999). During the summer season, the villagers in our study area sleep outside of their houses and keep their animals in open shelters where we set our traps. Therefore, potential hosts for sand fly species during the night are available. The 
significant male biased sex ratio we observed during our study may be explained by this adaptive behaviour.

Our data demonstrate the existence of important vector species of sand flies in the study area. Phlebotomus tobbi is the predominant species and abundant from May to October with a continuous nocturnal activity. Although the abundance of this sand fly species is not by itself sufficient to incriminate it as a vector, it is clear that $P$. tobbi could potentially transmit leishmaniasis in this endemic focus. Further studies should focus on P. tobbi to confirm the sand fly species transmitting leishmaniasis in this region.

\section{Aktivita některých druhů dvoukřídlého hmyzu z čeledi Psychodidae a porovnání účinnosti rủzných typů pastí v endemických ohniscích kožní leishmaniózy soustřreděných v oblasti Cukurova Plain, jižní Anatolie, Turecko}

Entomologický průzkum dvoukřídlého hmyzu z čeledi Psychodidae byl prováděn v období od května do října 2006 v jedné z vesnic nedaleko endemického ohniska kožní leishmaniózy v oblasti Cukurova Plain, jižní Anatolie v Turecku. Pro sběr hmyzu byly použity standardní metody odchytu pomocí CDC světelných pastí, $\mathrm{CO}$, pastí, lepů, ručních aspirátorů, lapačů na návnadu a pomocí metody „human landing collection” pro určení druhového zastoupení, hustoty a noční aktivity těchto druhů. Dále byla testována efektivita a využití nové monitorovací pasti BG-Sentinel Trap pro druhy čeledi Psychodidae, původně určené k odchytu komárů. Celkem bylo získáno 4048 exemplářủ patřících do čtyř druhů rodu Phlebotomus Rondani et Berte 1840 a dvou druhů rodu Sergentomyia Franca et Parrot 1920. Nejvíce zastoupeným (65.6\%) druhem byl Phlebotomus tobbi Adler, Theodor et Lourie 1930, prokázaný vektor Leishmania infantum Nicolle 1908, zatímco P. sergenti Parrot 1917, prokázaný vektor $L$. tropica (Wright 1903 ) v Turecku, tvořil pouze $0.1 \%$ identifikovaných jedinců této skupiny hmyzu. Další druhy, P. perfiliewi galilaeus (Theodor 1958), P. papatasi (Scopoli 1786), Sergentomyia dentata (Sinton 1933) a Sergentomyia theodori (Parrot 1942) reprezentovaly $31 \%, 2 \%, 1.5 \%$ a $0.3 \%$ exemplářů této skupiny hmyzu, v tomto pořadí. Četnost populací dvoukř́idlého hmyzu z čeledi Psychodidae bylo nejslabší v květnu. Velikost populací narůstala během června a července, kulminovala v srpnu, a redukovala se během záŕí a října. Za nejvhodnější a nejproduktivnější metodu odchytu hmyzu čeledi Psychodidae lze z použitých metod považovat $\mathrm{CO}$ pasti, které se osvědčily jak pro odhad druhové skladby hmyzu, tak pro zjištění populační hủstoty těchto druhů v námi zvolené oblasti. Při studiu noční aktivity zmíněných druhů bylo také zaznamenáno snížené množství odchyceného hmyzu během soumračné fáze dne, mezi 04.00 a 06.00 h, jinak nebyly pozorovány žádné změny druhového složení ani noční aktivity v závislosti na časovém úseku během noci. Podle výsledků statistické analýzy bylo zjištěno, že noční aktivita není ovlivňována změnami teploty během noci, ale je silně spjata s relativní vlhkostí vzduchu.

\section{Acknowledgements}

We thank Prof. Petr Volf and Dr. Jan Votýpka of the Department of Parasitology, Faculty of Science, Charles University, Prague, Czech Republic for providing the BG-Sentinel Traps. This work was funded by the Scientific and Technological Research Council of Turkey and Hacettepe University Scientific Researches Unit.

\section{References}

Alexander B 2000: Sampling methods for phlebotomine sandflies. Med Vet Entomol 14: 109-122

Anonymous 2007: Cukurova University Tropical Diseases Research Center Records (www.cu.edu.tr)

Artemiev MM 1980: A revision of sandflies of subgenus Adlerius (Diptera, Phlebotominae, Phlebotomus). Zool Zhurnal 59: 1177-1192 (in Russian)

Beavers GM, Hanafi HA, Dykstra EA 2004: Evaluation of 1-octen-3-ol and carbon dioxide as attractants for Phlebotomus papatasi (Diptera: Psychodidae) in Southern Egypt J Am Mosq Control Assoc 20: 130-133

Bernier UR, Hoel DF, Hogsette JR JA, Hanafi HA, Kline DL 2008: Effect of lures and trap placement on sand fly and mosquito traps. Proceedings of the $6^{\text {th }}$ International Conference on Urban Pests, $13-16$ July 2008. Budapest, Hungary, pp. 171-175 
Büttiker W, Lewis DJ 1983: Insects of Saudi Arabia. Some ecological aspects of Saudi Arabian Phlebotomine sandflies (Diptera: Psychodidae). Fauna Saudi Arabia 5: 479-528

Coleman RE, Burkett DA, Sherwood V, Caci J, Spradling S, Jennings BT, Rowton E, Gilmore W, Blount K, White CE, Putnam JL 2007: Impact of Phlebotomine sandflies on U.S. military operations at Tallil Air Base, Iraq: 2. Temporal and geographic distributions of sandflies. J Med Entomol 44: 29-41

Dinesh DS, Das P, Picado A, Davies C, Speybroeck N, Boelaert M, Coosemans M 2008: The efficacy of indoor CDC light traps for collecting the sand fly Phlebotomus argentipes, vector of Leishmania donovani. Med Vet Entomol 22: 120-123

Dye C, Davies CR, Lainson R 1991: Communication among phlebotomine sandflies: a field study of domesticated Lutzomyia longipalpis populations in Amazonian Brazil. Anim Behav 42: 183-192

Guernaoui S, Boussaa S, Pesson B, Boumezzough A 2006: Nocturnal activity of phlebotomine sandflies (Diptera: Psychodidae) in a cutaneous leishmaniasis focus in Chichaoua, Morocco. Parasitol Res 98: 184-188

Killick-Kendrick R, Tang, Killick-Kendrick M, Sang DK, Sirdar MK, KE L, Ashford RW, Schorscher J, Johnson RH 1991: The identification of female sandflies of the subgenus Larroussious by the morphology of the spermatechal ducts. Parasitologia 33 (Suppl.): 335-347

Lewis DJ 1982: A taxonomic review of the genus Phlebotomus (Diptera: Psychodidae). Bull Br Mus Nat Hist Entomol 45: 121-129

Killick-Kendrick R 1999: The biology and control of Phlebotomine sandflies. Clin Dermatol 17: 279-289

Maciel-de-Freitas R, Eiras AE, Lourenço-de-Oliveira R 2006: Field evolution of effectiveness of the BG-Sentinel, a new trap for capturing adult Aedes aegypti (Diptera: Culicidae). Mem Inst Oswaldo Cruz 101: 321-325

Morrison AM, Ferro C, Pardo R, Torres M, Wilson ML, Tesh RB 1995: Nocturnal activity patterns of Lutzomyia longipalpis (Diptera: Psychodidae) at an endemic focus of visceral leishmaniasis in Colombia. J Med Entomol 32: $605-617$

Ostfeld RS, Roy P, Haumaier W, Canter L, Keesing F, Rowton ED 2004: Sand fly (Lutzomyia vexator) (Diptera: Psychodidae) populations in upstate New York: abundance, microhabitat, and phenology. J Med Entomol 41: 774-778

Quinnell RJ, Dye C. 1994: Correlates of the peridomestic abundance of Lutzomyia longipalpis (Diptera: Psychodidae) in Amazonian Brazil. Med Vet Entomol 8: 219-224

Reza FM, Mansour N 2006: Entomological studies of Phlebotomus papatasi and P. sergenti (Diptera: Psychodidae) as vectors of cutaneous leishmaniasis in Shiraz, Iran. Southeast Asian J Trop Med Public Health 37: 115-117

Roberts DM 1994: Arabian sandflies (Diptera: Psychodidae) prefer the hottest nights? Med Vet Entomol 8: 194-198

Seyedi Rashti MA, Nadim A 1992: The genus Phlebotomus (Diptera: Psychodidae: Phlebotominae) of the countries of the eastern Mediterranean region. Iran J Publ Health 21: 11-50

Simsek FM, Alten B, Caglar SS, Ozbel Y, Aytekin AM, Kaynas S, Belen A, Erisoz Kasap O, Yaman M, Rastgeldi S 2007: Distribution and altitudinal structuring of phlebotomine sandflies (Diptera: Psychodidae) in southern Anatolia, Turkey: their relation to human cutaneous leishmaniasis. J Vector Ecol 32: 269-279

Singh KV 1990: Studies on the role of climatological factors in the distribution of Phlebotomine sandflies (Diptera: Psychodidae) in semi-arid areas of Rajasthan, India. J Arid Environ 42: 43-48

Svobodová M, Alten B, Zídková L, Dvořák V, Hlavačková J, Myšková J, Šeblová V, Kasap OE, Belen A, Votýpka J, Volf P 2009: Cutaneous leishmaniasis caused by Leishmania infantum transmitted by Phlebotomus tobbi. Int J Parasitol 39: 251-256

Theodor O 1958: Psychodidae - Phlebotominae. In: Lindner E (Ed.): Die fliegen der Palearktischen Region. E. Schweizerbartsche Verlags Stuttgart Germany, pp. 1-55

Veronesi E, Pilani R, Carrieri, Bellini R 2007: Trapping sandflies (Diptera: Psychodidae) in the Emilia-Romagna region of Northern Italy. J Vector Ecol 32: 313-318

Wheeler AS, Feliciangeli MD, Ward RD, Maingon RDC 1996: Comparison of sticky-traps and CDC light-traps for sampling phlebotomine sandflies entering houses in Venezuela. Med Vet Entomol 10: 295-29 